Richard Fedorko,

Associate Professor, University of Presov, Slovakia

(iD) ORCID ID, 0000-0003-3520-1921

email: richard.fedorko@unipo.sk

Veronika Skerhakova,

Ph.D., University of Presov, Slovakia

(iD) ORCID ID, 0000-0003-2170-1837

email: veronika.skerhakova@unipo.sk

Stela Markova,

Ph.D.,University of Presov, Slovakia

(iD) ORCID ID, 0000-0001-7275-1936

email:markova.stela@gmail.com

Radovan Bacík,

Associate Professor, University of Presov, Slovakia

ORCID ID, 0000-0002-5780-3838

email: radovan.bacik@unipo.sk

Lubomir Fejercak,

University of Presov, Slovakia

(iD) ORCID ID, 0000-0001-7120-1844

email: fejercak@gmail.com

Correspondence author: richard.fedorko@unipo.sk

\title{
DIFFERENCES IN THE PERCEIVED FINANCIAL RISK FACTORS BETWEEN DIGITAL NATIVES IN THE E-COMMERCE
}

Abstract. Financial risk in the e-commerce environment includes the fear of the misusing of payment and personal data, which is based on the previous reputation of the e-shop, regarding the choice of payment method and the height of the amount willing to pay during a single online purchase. Systematization of literary sources and approaches for solving the problem of financial risk perception by online consumers indicates that the investigation of this issue is important for building the trustworthiness and loyalty of the e-commerce subjects. That activates the online consumers to spend more finances by shopping online. Based on intergenerational comparative analysis between the Digital Natives generations, the main purpose of this research is to examine differences in their perception of the financial risk factors in the e-commerce environment. The data were obtained by questionnaire survey and processed by selected nonparametric mathematical-statistical quantitative methods as Pearson $X^{2}$ test and Wilcoxon unpaired signed-rank test. The research sample consisted of 758 respondents of both examined generations. Five financial factors were selected to examine differences in their perception by generations belonging to the Digital Natives in the research. The paper presents the results of an empirical intergenerational comparative analysis between Generation $Y$ and Generation $Z$ in the field of selected problematics, which showed that the Generation $Y$ representatives are statistically significantly more willing to provide their personal and payment data compared to the Digital natives belonging to the Generation Z. It means that the older generation is much more identified with the e-commerce environment and its special attributes. The research also confirmed the presence of the statistically significant differences between the examined generations on the level of perception of fear from the misusing personal and payment data, where the Generation Y representatives stated significantly more worries about the misusing of their personal and payment data when shopping online. The study revealed that Generation $Y$ representatives are more willing to pay a statistically significant higher price than Generation Z members during one online purchase. Their female representatives stated the statistically significantly higher amount of the disposable monthly budget for purchases (excluding food expenditures) than the Generation Z females. The obtained results showed no differences

Cite as: Fedorko, R., Skerhakova, V., Markova, S., Bacik, R., \& Fejercak, L. (2021). Differences in the Perceived Financial Risk Factors between Digital Natives in the E-Commerce. Marketing and Management of Innovations, 4, 137-152. http://doi.org/10.21272/mmi.2021.4-11 
R., Fedorko, V., Skerhakova, S., Markova, R., Bacik, L., Fejercak. Differences in the Perceived Financial Risk Factors between Digital Natives in the E-Commerce

in the level of perception in the importance of the previous reputation of the e-shop in the shopping decisions and the preferred payment method of the representatives of both examined generations, based on the same degree of consent with these factors. The research empirically confirms and theoretically proves significant differences in the perception of factors determining financial risk by Digital Natives in the e-commerce environment. The research results also have practical managerial and marketing implications, which could be useful for online sellers, e-merchants, and digital advertising agencies to evolve and adapt marketing strategies based on understanding the different needs and desires of examined generations.

Keywords: financial risk, intergenerational analysis, Millennials, online consumer behavior, payment fraud, PostMillennials.

Introduction. E-commerce has been traditionally used to refer to the process of selling and purchasing goods and services over a variety of electronic systems (typically based on the Internet and other digital networks). It has its unique specific attributes of modern trading in the digital world (Al Mazrouei and Krotov, 2016). The issue of e-commerce is closely related to the perceived financial risk through preferred payment methods and willingness to provide personal and payment data while shopping online. That reflects the e-commerce subject's reputation and online consumers' loyalty (Pencarelli et al., 2018). Financial risk measures a consumer's concern about the monetary loss when shopping through the Internet. It is related to the consumer's feeling at risk of losing money (Aldhmour and Sarayrah, 2016). The young online consumers' innovative perspective on this topic (called Digital natives) comes with a rapidly changing e-commerce environment and implementing digital payment methods. This study considers generation $Y$ and generation $Z$ (as representatives of Digital natives), grown up with different types of technology since their early childhood. Thus, it is expected that their shopping and consumer behavior will transfer exclusively to the field of digital space in the future. Online consumer behavior in the e-commerce environment is considered to be one behaviorist complex issue in marketing research. The decision-making process is based on relevant demographic, psychological, cultural, and socio-economic factors and the consumer's individuality. Each generation (from Generation of Baby Boomers to Generation Z) is influenced by different factors affecting shopping behavior in the online e-commerce environment. Understanding differences in consumer behavior and attitudes of representatives of each generation is important for sellers in e-commerce and digital advertising agencies (Ungerman et al., 2018). Thanks to the findings from these problematics, they could influence consumers' purchasing decisions because nowadays, consumers decide what to buy and where to buy due to the huge competition in the e-commerce market. When shopping online, consumers evaluate all available shopping alternatives. They choose the best to fulfill their perceived needs concerning minimizing purchasing risks in the e-commerce environment. According to Deloitte (2019), Generation Y and Generation Z representatives would represent more than $40 \%$ of the total number of consumers by 2025 . Thus, this research focused on intergenerational comparative analysis of the perception of the financial risk factors in the e-commerce environment.

Literature Review. According to Ryder (1965), a generation could be defined as a group of individuals of a similar age who share historical experiences at the same time. A generational cohort shares are important life stages like studying, entering employment, and retiring at the same age. They also experience historical events at a similar stage of their lives (Kowske et al., 2010). Some studies investigated the differences between generations (Baby Boomers, Generations $X$ and $Y$ ). They revealed that there are significant differences between their typical personality characteristics, consumers' behavior, and in the field of employment, there are differences in their work attitudes and values. The Digital Natives employees want to take part in decision-making in the company and not just listen to what the manager tells them (Deloitte, 2019; Chen and Choi, 2007; Gallo et al. 2019; Jurkiewicz, 2000; Wey Smola and Sutton, 2002). Generations $Y$ and $Z$ (Digital Natives) are the first generations that spent their entire lives in the digital environment. Information technology profoundly affects their lifestyle, work, and consumer 
R., Fedorko, V., Skerhakova, S., Markova, R., Bacik, L., Fejercak. Differences in the Perceived Financial Risk Factors between Digital Natives in the E-Commerce

behavior (Bolton, 2013). They are all united by being part of the present and upcoming Digital Natives generations in history, familiar with using digital technology and communication in adulthood (Bianchi, 2016). Almost all Digital Natives consumers appreciate the possibility of being connected at any time and place. They are digital, global (but interested in the local world), and hyper-connected. They are very similar in using information technology, especially the use of social media sites, where $97 \%$ of them have at least one personal profile on a social network: excluding WhatsApp, which remains the most used messaging platform, Facebook is still fundamental, followed by Instagram, YouTube, and Pinterest (Hanan et al., 2018). They are motivated to use social media sites to gain more «likes» while the older generation (i.e., digital immigrants) are motivated more by staying in touch with friends and family. In general, they are very good at recognizing an advertising message and could distinguish authentic content from a promotional one (Fietkiewicz, 2017; Magnani et al., 2018).

Generation Y members are «Millennials», born between 1980-1995. They represent $24 \%$ of the whole world's population (Bianchi, 2016). Generation Y might be conventionally divided into two age cohorts: 1) between 25-30 years; 2) between 31-40 years (Barton et al., 2014). The elder part of Millennials has experienced long periods of economic prosperity (until the past few years). A rapid advance in instant communication technologies, social networking, and globalization compared to the younger one was challenged by recession effects and economic turbulences (Bolton, 2013), such as the world crisis in 2008. These external events have shaped Generation $Y$ consumer behavior and their digital technologies and environment. According to Park and Gursoy (2012), their formative attribute is early and frequent exposure to technology, which has advantages and disadvantages in terms of cognitive, emotional, and social outcomes (for example, they rely heavily on technology for entertainment, to interact with others and even for emotion regulation).

Members of the younger generation Z cohort were born between 1995-2010. They are called PostMillennials (Bianchi, 2016). The representatives of this generation are highly pragmatic individuals, born at a time of profound global and ideological crisis. They use an average of five devices (compared to Millennials who use only three): smartphones, desktops, tablets, notebooks, TVs. They have grown along with the iPhone, and instead of words, they use emojis (Paganini, 2019). Concerning using smartphones, Post-Millennials are representatives of «The Gamers» and «The Supersmartphoners» users. It means they use smartphones basically for fun, but $61 \%$ of them use the smartphone also for working (De Canio et al., 2016).

Generation $Y$ consumers are interested in innovative and customized products and personalized services that best fit them. They are representatives of the lifestyle: «I want it all, and I want it now» as in the consumer behavior and concerning work and life balance, interesting work, and being able to contribute to society via their work (Korzeniowska, 2015).

They want better and more innovative products as quickly and conveniently as possible. Millennials are willing to order FMCG (fast-moving consumers goods) online with home delivery almost double times often as in the case of Generation Z (Bianchi, 2016). The increase in the online sales of consumer goods is partly due to the digital maturity reached by the Digital Natives. According to the Davidaviciene et al. (2019) case study, the main factors influencing generation $Y$ consumers' buying decisions are demographic features, reputation, trustworthiness, safety, price, and the possibility to digitalize. Based on Oczachowskas' research (2020), it is evident that the representatives of Generation Y are not afraid of purchasing products over the Internet. Millennials are more oriented to spend their money than Generation $Z$ representatives, who prefer to save their money. Following these statements, the first hypothesis was formulated assuming the difference in the amount of the highest price the respondents are willing to pay during a single online purchase:

$\mathrm{H} 1$ : There is a statistically significant difference in the price, which the respondents are willing to pay during a single online purchase between Generation $Y$ and Generation $Z$ representatives. 
R., Fedorko, V., Skerhakova, S., Markova, R., Bacik, L., Fejercak. Differences in the Perceived Financial Risk Factors between Digital Natives in the E-Commerce

Prokopenko et al. (2016) stated that the new economics definition is associated with «e-commerce», which is developing at a high pace worldwide. Undoubtedly, the internet trade, which has put roots in the commercial market, is considered to be the base for e-commerce. Many factors explain the prosperity of online trade. According to Lyulyov et al. (2018), the new forms of competition compel managers at a different level (companies, countries) to seek more complicated methods of obtaining a competitive advantage, especially in intangible factors. Stefko et al. (2013) stated the essential factors of reaching a competitive advantage to the consumers' trustworthiness to the e-commerce subjects are communication, image, and reputation, which are conjunct. The current image of a subject is usually based on its previous reputation. Therefore and following the above arguments, it was proposed and formulated the second hypothesis:

$\mathrm{H} 2$ : There is a statistically significant difference in the level of perception in the importance of the previous reputation of the e-shop in the shopping decisions between Generation $Y$ and Generation $Z$ representatives.

Perceived risk associated with online purchasing in e-commerce is defined as a consumer's belief about the potential losses or other negative outcomes from transacting on the Internet. It includes social, financial, physical, performance, time, psychological and security risks. These risks are great barriers to the online purchase intention of customers (Muhammad Shafeeque and Thomachan, 2017; Wright, 2016). Security risk refers to the threat of a security breach of personal information that people submit online. When a store has a higher perceived security risk, the consumer is less likely to intend to make a purchase. According to Wright's (2016) research, consumers agreed that their personal information is secure without security risk. They do have a higher intention to purchase from the website. The perceived security of a website heavily influences the intention to purchase on that website. Kubilay and Bayrakdaroğlu (2016) stated that financial risk is a factor forming the financial decisions of individuals. Financial risk tolerance presents their willingness to make a financial decision in case of maximum uncertainty. Another factor that is as effective as risk tolerance in financial decision-making is personality traits of individuals such as abilities, emotions, motives, nature; physical-psychomotor, social, and cognitive traits; attitudes, beliefs, personality, and values (Kleinman, 2012). Financial risk measurement is a largely investigated research area; its relationship with imprecise probabilities has been mostly overlooked (Valaskova et al., 2018). Financial risk means loss of money, especially in terms of online shopping. Noteworthy here represents the loss of money due to poor product, service choice, bad purchase, or fraud. Credit /debit card fraud is a primary financial concern among many online consumers (Thandava and Viju, 2017). McQuivey (2000) reported the top reasons young consumers do not shop online and the most important deterrent to online shopping concerns credit/debit card security. Indeed, credit/debit card misusing fears are often reported as a major deterrent to online shopping.

According to Michalski et al. (2015), e-commerce carries specific elements of modern trading methods. Its main specific attribute is non-cash payment through credit/debit card, direct bill payment, and other electronic payment methods. Teltzrow et al.(2007) have found that perceived privacy concerns have the strongest influence on trust in the e-shop, followed by perceived reputation. The higher the perceived experience risk, the consumer may shift to brick-and-mortar retailers to purchase the product. Whereas the lower the perceived risk, the higher the propensity for online shopping (Tan,1999). Thus, fear of losing money, payment, and personal details negatively affect attitude toward online shopping (Javadi et al., 2012). Hence, we derived the following hypotheses:

$\mathrm{H} 3$ : There is a statistically significant difference in the willingness to provide personal and payment data between Generations $Y$ and $Z$ representatives.

$\mathrm{H} 4$ : There is a statistically significant difference in perception of fear from misusing personal and payment data between Generations $Y$ and $Z$ representatives.

Horvath et al. (2014) stated there are only a few innovations in history, including as many benefits as e-commerce does. The technological development, the ability to reach out to a huge group of people, its 
R., Fedorko, V., Skerhakova, S., Markova, R., Bacik, L., Fejercak. Differences in the Perceived Financial Risk Factors between Digital Natives in the E-Commerce

interactive nature, the diversity of opportunities to use it, or the rapid growth of its supporting infrastructures result in many potential benefits for organizations, individuals, and society. The industry of e-commerce has attracted millions of online consumers by creating a secure online transaction environment. Guo et al. (2012) confirmed that the design, security, payment method, etc., of the e-commerce subjects (particularly e-shops), play an important role in building consumers' positive reputation and loyalty. The importance of the availability of consumers' preferred payment method is undeniable and comes with their loyalty and satisfaction. According to Halaweh (2018), a credit card is globally the most preferred e-payment method. On the other hand, there is the COD (cash-on-delivery), which differs from all other payment methods in terms of time and place of payment, processing, and parties involved, as well as security and privacy assurance. The huge COD advantage for the customer lies in the cash payment realization when a product is delivered to their home or the preferred location. This method is also named the «post-payment» system because the customer receives goods before payment. Following the above arguments, the study derived the following hypothesis:

$\mathrm{H} 5$ : There is a statistically significant difference in the preferred payment method between Generations $Y$ and $Z$ representatives.

Methodology and research methods. The paper aims to examine differences in the perception of the financial risk factors between Digital Natives in the e-commerce environment, based on the intergenerational comparative analysis between Generations $Y$ and $Z$. The primary data were obtained by the questionnaire method in November 2019 in the Slovak Republic. The selection of a research sample suitable for intergenerational comparative analysis was carried out by purposive sampling. Our sample size consisted of 758 respondents, representing Generation Y (born between 1980-1995) and Generation Z (born between 1995-2010). Both of these examined generations are considered to be members of the Digital Natives in the e-commerce environment. They would represent the largest share of the future consumers in the global market (Deloitte, 2019).

This research worked with categorical variables identified on a dichotomous nominal scale (e.g., gender, residence) and variables identified on an ordinal Likert scale (which consisted of a rating scale containing 5 responses). It focused on conducting this information by verifying hypotheses through quantitative statistical methods through a wide range of research. The absolute numbers of values were used as input data for Pearson's $X^{2}$ test, determining the presence of statistically significant differences between these two groups of generations ( $Y$ and $Z$ ). The data were also converted to the relative frequency of dominance of individual responses. Blaker's confidence interval $(\mathrm{Cl})$ for discrete data was calculated exactly at $95 \%$ (Blaker, 2000). Thus, it allows the generalization of findings based on a smaller research data sample to a larger population group.

Wilcoxon's unpaired signed-rank test is a nonparametric statistical hypothesis test (Hollander and Wolfe, 1999). The basic principle of this test is the testing of the null hypothesis in which it is assumed that the medians of both compared groups are identical. If the null hypothesis $(p>0.05)$ is confirmed, the medians of the two groups compared are not statistically different. Suppose the null hypothesis is not confirmed $(p<0.05)$, the alternative hypothesis is accepted, i.e., the median values differ statistically between the compared groups. To find out the information about our continual variables as «Age» and «Disposable budget for monthly purchases(excluding food expenditures)», the descriptive statistics measures were used: of central tendency - sample mean and median; of variability - standard deviation (SD); of the minimum and maximum values of variables (min-max). The following methods were used to evaluate the obtained data: analysis, synthesis, comparison, induction, and deduction. The statistical hypotheses were verified by software $R$ version 3.6.1(R Core Team 2019), and all tables were created and formatted in MS Excel.

Based on the main purpose of this research, the focus was on the following individual intergenerational differences in the perception of these financial risk factors by the young consumers in the e-commerce environment: 
R., Fedorko, V., Skerhakova, S., Markova, R., Bacik, L., Fejercak. Differences in the Perceived Financial Risk Factors between Digital Natives in the E-Commerce

- Factor 1: the amount of the price that the respondents are willing to pay during a single online purchase,

- Factor 2: the importance of the previous reputation of the e-shop,

- Factor 3: the level of willingness to provide personal and payment data,

- Factor 4: the level of perception of fear from misusing personal and payment data,

- Factor 5: preferred payment method.

Based on these selected factors of perception of financial risk, in our research, five following statistical hypotheses in the name of fulfilling the research aim were formulated:

Hypothesis 1

$\mathrm{HO}$ : There is a statistically significant difference in the price, which the respondents are willing to pay during a single online purchase between the Generations $Y$ and $Z$ representatives.

$\mathrm{H} 1$ : There is no statistically significant difference in the price amount, which the respondents are willing to pay during a single online purchase between the Generations $Y$ and $Z$ representatives.

Hypothesis 2

$\mathrm{HO}$ : There is a significant difference in perception of the importance of the previous reputation of the e-shop in the shopping decisions between the Generations $Y$ and $Z$ representatives.

$\mathrm{H} 1$ : There is no significant difference in the level of perception in the importance of the previous reputation of the e-shop in the shopping decisions between the Generations $Y$ and $Z$ representatives.

Hypothesis 3

$\mathrm{HO}$ : There is a significant difference in the level of willingness to provide personal and payment data between the Generations $Y$ and $Z$ representatives.

$\mathrm{H} 1$ : There is no significant difference in the level of willingness to provide personal and payment data between the Generations $Y$ and $Z$ representatives.

Hypothesis 4

$\mathrm{HO}$ : There is a significant difference in the perception of fear from misusing personal and payment data between the Generations $Y$ and $Z$ representatives.

$\mathrm{H} 1$ : There is no significant difference in the perception of fear from misusing personal and payment data between the Generations $Y$ and $Z$ representatives.

Hypothesis 5

$\mathrm{HO}$ : There is a statistically significantly different preferred payment method between the Generations $\mathrm{Y}$ and $\mathrm{Z}$ representatives.

$\mathrm{H} 1:$ There is no statistically significant difference in the preferred payment method between the Generations $Y$ and $Z$ representatives.

Results. Although the purpose of this paper was focused on the intergenerational comparison, based on which it was necessary to investigate the age of the respondents. Additional questions were formulated to determine respondents' gender, educational attainment, and residence in the questionnaire survey. The question concerning the «disposable amount of monthly income» of respondents was in this case replaced by a question about the «amount of disposable monthly budget for monthly purchases (excluding food expenditures)» because the first option was in our previous research evaluated as very sensitive information. Of the 758 respondents, 282 respondents (37.2\%) were representatives of Generation $Y$, and 476 respondents were representatives of Generation $Z(62.8 \%)$. Within the respondents belonging to Generation $Y, 211$ representatives (75\%) were of the female gender and 71 representatives $(25 \%)$ - of the male gender. Within the younger representatives of Generation Z, a significant predominance was observed for 351 female respondents, representing $74 \%$ of all of the Generation $Z$ respondents in this research. Male gender respondents belonging to Generation Z represented $26 \%$ (125 respondents).

According to the analysis of educational attainment of this research sample, the most numerous group within Generation Z consisted of high school graduated respondents (363), representing $76 \%$ of all 
R., Fedorko, V., Skerhakova, S., Markova, R., Bacik, L., Fejercak. Differences in the Perceived Financial Risk Factors between Digital Natives in the E-Commerce

Generation $Z$ representatives. The analysis of the educational attainment of the older Generation $Y$ showed that the most numerous group (with the count of 133) became graduates of Master's degree, which is quite logical, as they are considered representatives of the older generation. In the case of Generation Z, Master's degree graduates are not present yet, due to their younger age.

Identification of the respondents' residence indicated a very balanced ratio of representatives living in the urban. In turn, $46 \%$ of all respondents of Generation $Y$ lived in the urban area, and $54 \%$ - in the rural area. The opposite phenomenon is visible within the representatives of Generation Z. Thus, $55 \%$ of them lived in the urban area, and $45 \%$ - rural. Tables 1 and 2 show the individual values of the demographic characteristics of the respondents.

Table1. Demographic characteristics of respondents I

\begin{tabular}{|c|c|c|c|c|c|c|c|}
\hline \multirow[b]{2}{*}{$\begin{array}{l}\text { Characteristics of } \\
\text { respondents }\end{array}$} & \multirow[b]{2}{*}{ Options } & \multicolumn{3}{|c|}{ Generation Y } & \multicolumn{3}{|c|}{ Generation Z } \\
\hline & & $\begin{array}{l}\text { Absolute } \\
\text { Frequency }\end{array}$ & $\begin{array}{l}\text { Relative } \\
\text { Frequency }\end{array}$ & $\begin{array}{l}95 \% \mathrm{Cl} \\
\text { (lower- } \\
\text { upper) }\end{array}$ & $\begin{array}{l}\text { Absolute } \\
\text { Frequency }\end{array}$ & $\begin{array}{l}\text { Relative } \\
\text { Frequency }\end{array}$ & $\begin{array}{l}95 \% \mathrm{Cl} \\
\text { (lower- } \\
\text { upper) }\end{array}$ \\
\hline \multirow[t]{2}{*}{ Gender } & Male & 71 & 0.255 & $0.2-0.31$ & 125 & 0.26 & $0.22-0.3$ \\
\hline & Female & 211 & 0.745 & $0.69-0.8$ & 351 & 0.74 & $0.7-0.78$ \\
\hline \multirow[t]{3}{*}{$\begin{array}{c}\text { Educational } \\
\text { attainment }\end{array}$} & $\begin{array}{c}\text { High School } \\
\text { Graduate }\end{array}$ & 41 & 0.15 & $0.11-0.19$ & 363 & 0.76 & $0.72-0.8$ \\
\hline & $\begin{array}{l}\text { Bachelor's } \\
\text { Degree }\end{array}$ & 108 & 0.38 & $0.35-0.40$ & 113 & 0.24 & $0.2-0.28$ \\
\hline & $\begin{array}{l}\text { Master's } \\
\text { Degree }\end{array}$ & 133 & 0.47 & $0.41-0.54$ & - & - & - \\
\hline \multirow[t]{2}{*}{ Residence } & Urban area & 131 & 0.465 & $0.41-0.52$ & 263 & 0.555 & $0.51-0.6$ \\
\hline & Rural area & 151 & 0.535 & $0.48-0.59$ & 213 & 0.445 & $0.4-0.49$ \\
\hline
\end{tabular}

Sources: developed by the authors.

The results of descriptive statistics indicated that the average age of respondents from Generation $Y$ was 26.41 years, while in the case of younger Generation $Z-20.33$. The median age of the Generation $Y$ representatives was 25 years, whereas Generation $Z-21$.

The question concerning the respondents' monthly income was replaced by the question identifying the amount of the disposable budget for monthly purchases (excluding food expenditures) of the respondents. It was found out that the average amount of this disposable budget of the Generation $Y$ representatives was $140 €$ per month, and the median amount was on the level of $110 €$. The Generation $Z$ representatives allocated a little less finance on this budget, where the average amount was $115 €$, and the median amount was stabilized on the level of $100 €$. The interesting findings regarding this phenomenon are the values of the sample median of this budget between examined generations. They are very close to each other, instead of the difference in the sample mean values. According to these findings, more representatives of Generation $Y$ dispones with the higher disposable budget for monthly purchases (excluding food expenditures) than the Generation $Z$ representatives (according to the minimum and maximum values). According to the results of the selected descriptive statistics measure of central tendency (mean), a nonparametric Wilcoxon unpaired signed-rank test was used to explore if there are any intergenerational statistical significant differences regarding this phenomenon.

Table 2. Descriptive statistics of the continual variables

\begin{tabular}{|c|c|c|c|c|}
\hline & & Generation $Y$ & & Generation Z \\
\hline $\begin{array}{c}\text { Demographic } \\
\text { characteristics } \\
\text { Descriptive statistics }\end{array}$ & Age & $\begin{array}{l}\text { Disposable budget for } \\
\text { monthly purchases } \\
\text { (excluding food expenditures) }\end{array}$ & Age & $\begin{array}{l}\text { Disposable budget for monthly } \\
\text { purchases } \\
\text { (excluding food expenditures) }\end{array}$ \\
\hline
\end{tabular}


R., Fedorko, V., Skerhakova, S., Markova, R., Bacik, L., Fejercak. Differences in the Perceived Financial Risk Factors between Digital Natives in the E-Commerce

\begin{tabular}{ccccc}
\hline Mean & 26.41 & 140.32 & 20.33 & 115.61 \\
Median & 25 & 110 & 21 & 100 \\
SD & 0.59 & 122.25 & 1.48 & 112.08 \\
Min-Max & $23-28$ & $0-1200$ & $17-22$ & $0-1000$ \\
\hline
\end{tabular}

Sources: developed by the authors.

From the results of the Wilcoxon unpaired signed-rank test summarized in the third table, it is obvious no statistically significant difference in the amount of disposable budget for monthly purchases (excluding food expenditures) between investigated generations. It was confirmed the presence of a statistically significant difference in the amount of disposable budget for monthly purchases between the female representatives of Generation $Y$ and Generation $Z$, where the amount of disposable budget of the Generation $Y$ females is significantly higher than the amount of the Generation $Z$ females.

Table 3. Differences in the height of the disposable budget for monthly purchases

\begin{tabular}{ccc}
\hline Wilcoxon unpaired signed test & $\mathbf{z}$ & $\mathbf{p}$ \\
\hline Generation Y vs. Generation Z & 2.26 & 0.126 \\
Generation Y vs. Generation Z & 0.78 & 0.436 \\
Males & & 0.022 \\
Generation Y vs. Generation Z & 2.29 & \\
\hline Females & & \\
\hline
\end{tabular}

Sources: developed by the authors.

The first hypothesis verified the presence of a statistically significant difference in the amount of the price, which the respondents are willing to pay during a single online purchase. The respondents could choose from five options of the high of the amount (max. 50€; max. 100€; max. 250€; max. 500€; >500€) they are willing to pay during one online purchase. The Pearson $X^{2}$ test was chosen for detecting intergenerational differences. In this case, statistically significant intergenerational differences were found out. Representatives of Generation $Y$ are more willing to pay a statistically significant higher amount of the price than younger respondents of Generation Z during one online purchase (Table 4). Based on the results of statistical verification by the Pearson $X 2$ test, the $\mathrm{H} 0$ hypothesis was accepted. Thus, the H1 hypothesis was rejected on the significance level $p<0,001$.

Table 4. Statistical verification of the first hypothesis

\begin{tabular}{cccc}
\hline Pearson X2 test & $X^{2}$ & $p$ & df \\
\hline $\begin{array}{c}\text { Generation Y vs. } \\
\text { Generation Z }\end{array}$ & 16.11 & 0.003 & 4 \\
\hline
\end{tabular}

Sources: developed by the authors.

Generation $Y$ were equally dominant two types of answers, namely «maximum $50 €$ » and «maximum $100 €$ ». On the other hand, the significantly dominant answer of Generation Z was «maximum $50 €$ ». These results of statistical verification allowed concluding that Generation Z representatives are willing to spend a lower amount on a single online purchase compared to Generation $Y$.

Table 5. Descriptive statistics and confidence intervals $(\mathrm{Cl})$ of the first hypothesis

\begin{tabular}{ccccccc}
\hline \multirow{3}{*}{ Options } & \multicolumn{3}{c}{ Generation $\mathrm{Y}$} & \multicolumn{3}{c}{ Generation Z } \\
\cline { 2 - 7 } & $\begin{array}{c}\text { Absolute } \\
\text { frequency }\end{array}$ & $\begin{array}{c}\text { Relative } \\
\text { Frequency }\end{array}$ & $\begin{array}{c}\text { 95\% Cl } \\
\text { (lower-upper) }\end{array}$ & $\begin{array}{c}\text { Absolute } \\
\text { frequency }\end{array}$ & $\begin{array}{c}\text { Relative } \\
\text { Frequency }\end{array}$ & $\begin{array}{c}95 \% \mathrm{Cl} \\
\text { (lower-upper) }\end{array}$ \\
\hline Max $€ 50$ & 110 & 0.39 & $0.33-0.45$ & 243 & 0.515 & $0.47-0.56$ \\
Max $€ 100$ & 98 & 0.35 & $0.29-0.41$ & 112 & 0.24 & $0.2-0.28$ \\
Max $€ 250$ & 52 & 0.185 & $0.14-0.23$ & 73 & 0.155 & $0.12-0.19$
\end{tabular}


R., Fedorko, V., Skerhakova, S., Markova, R., Bacik, L., Fejercak. Differences in the Perceived Financial Risk Factors between Digital Natives in the E-Commerce

\begin{tabular}{ccccccc}
\hline & & & & & & \\
Max $€ 500$ & 14 & 0.055 & $0.03-0.08$ & 26 & 0.06 & $0.04-0.08$ \\
$>€ 500$ & 8 & 0.03 & $0.01-0.05$ & 22 & 0.05 & $0.03-0.07$ \\
\hline
\end{tabular}

Sources: developed by the authors.

By assuming a statistically significant difference in perception in the importance of the previous reputation of the e-shop in the shopping decisions between Generation $Y$ and $Z$ representatives was made the statistical verification of the second hypothesis. In this case, the verification was done by Pearson $\mathrm{X}^{2}$ test considered as the best-fitted test to reveal the differences between two observed samples. The Pearson X2 test results show that the null hypothesis cannot be accepted at the significance level $p<0,05$ and the degrees of freedom 4 (Table 6). The importance of the previous reputation of the e-shop in the shopping decisions representatives of both examined generations stated at the same level of their perception with dominant answers «Agree» and «Strongly Agree» (Table 7).

Table 6. Statistical verification of the second hypothesis

\begin{tabular}{cccc}
\hline Pearson X2 test & $\mathbf{X}^{2}$ & $\mathbf{p}$ & df \\
\hline $\begin{array}{c}\text { Generation Y vs. } \\
\text { Generation Z }\end{array}$ & 3.43 & 0.488 & 4 \\
\hline
\end{tabular}

Sources: developed by the authors.

The previous reputation of the e-shop is also consistently important in determining the credibility of the e-shop for most consumers of both generations. $76 \%$ of Generation $Y$ and $75 \%$ of Generation $Z$ representatives agreed with the importance of this factor on their shopping decisions. Therefore, it was stated that the representatives of both examined generations would first check the reputation of the eshop before providing their personal and payment information and making their online purchases. This research revealed no significant differences in the level of perception in the importance of the previous reputation of the e-shop in the shopping decisions representatives of both examined generations, on the same degree of consent with this factor.

Table 7. Descriptive statistics and confidence intervals (CI) of the second hypothesis

\begin{tabular}{|c|c|c|c|c|c|c|}
\hline \multirow{2}{*}{$\begin{array}{c}\text { The reputation of } \\
\text { the e-shop }\end{array}$} & \multicolumn{3}{|c|}{ Generation Y } & \multicolumn{3}{|c|}{ Generation Z } \\
\hline & $\begin{array}{l}\text { Absolute } \\
\text { Frequency }\end{array}$ & $\begin{array}{c}\text { Relative } \\
\text { Frequency }\end{array}$ & $\begin{array}{c}95 \% \mathrm{Cl} \\
\text { (lower-upper) }\end{array}$ & $\begin{array}{l}\text { Absolute } \\
\text { Frequency }\end{array}$ & $\begin{array}{c}\text { Relative } \\
\text { Frequency }\end{array}$ & $\begin{array}{c}95 \% \mathrm{Cl} \\
\text { (lower-upper) }\end{array}$ \\
\hline Strongly disagree & 9 & 0.04 & $0.02-0.06$ & 14 & 0.035 & $0.02-0.05$ \\
\hline Disagree & 15 & 0.06 & $0.03-0.09$ & 29 & 0.065 & $0.04-0.09$ \\
\hline $\begin{array}{l}\text { Neither agree nor } \\
\text { disagree }\end{array}$ & 43 & 0.155 & $0.11-0.2$ & 75 & 0.16 & $0.13-0.19$ \\
\hline Agree & 119 & 0.42 & $0.36-0.48$ & 225 & 0.475 & $0.43-0.52$ \\
\hline Strongly agree & 96 & 0.345 & $0.29-0.4$ & 133 & 0.28 & $0.24-0.32$ \\
\hline
\end{tabular}

Sources: developed by the authors.

The results of statistical verification of the third hypothesis by Pearson $X^{2}$ test showed that generation $Y$ representatives are more willing to provide their personal and payment data to the e-commerce market subjects than Generation Z (the same results are valid for both genders). Based on the results of statistical verification by the Pearson $\mathrm{X}^{2}$ test, the $\mathrm{H} 0$ hypothesis could be accepted. Thus, the $\mathrm{H} 1$ hypothesis was rejected on the significance level $p<0,01$ and the degrees of freedom 4 (Table 8 ).

Table 8. Statistical verification of the third hypothesis

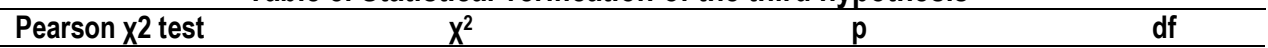


R., Fedorko, V., Skerhakova, S., Markova, R., Bacik, L., Fejercak. Differences in the Perceived Financial Risk Factors between Digital Natives in the E-Commerce

\begin{tabular}{ccc}
\hline $\begin{array}{c}\text { Generation Y vs. } \\
\text { Generation Z }\end{array}$ & 0.007 & 4 \\
\hline
\end{tabular}

Sources: developed by the authors.

Table 9. Descriptive statistics and confidence intervals (CI) of the third hypothesis

\begin{tabular}{ccccccc}
\hline \multirow{2}{*}{ Options } & \multicolumn{3}{c}{ Generation Y } & \multicolumn{3}{c}{ Generation Z } \\
\cline { 2 - 7 } & $\begin{array}{c}\text { Absolute } \\
\text { Frequency }\end{array}$ & $\begin{array}{c}\text { Relative } \\
\text { Frequency }\end{array}$ & $\begin{array}{c}\mathbf{9 5} \% \mathbf{C l} \\
\text { (lower-upper) }\end{array}$ & $\begin{array}{c}\text { Absolute } \\
\text { Frequency }\end{array}$ & $\begin{array}{c}\text { Relative } \\
\text { Frequency }\end{array}$ & $\begin{array}{c}\mathbf{9 5 \%} \mathrm{Cl} \\
\text { (lower-upper) }\end{array}$ \\
\hline $\begin{array}{c}\text { Strongly disagree } \\
\text { Disagree }\end{array}$ & 41 & 0.15 & $0.11-0.19$ & 92 & 0.195 & $0.16-0.23$ \\
$\begin{array}{c}\text { Neither agree nor } \\
\text { disagree }\end{array}$ & 92 & 0.325 & $0.27-0.38$ & 167 & 0.35 & $0.31-0.39$ \\
$\quad$ Agree & 57 & 0.205 & $0.16-0.25$ & 109 & 0.23 & $0.19-0.27$ \\
Strongly agree & 66 & 0.305 & $0.25-0.36$ & 91 & 0.195 & $0.16-0.23$ \\
\hline
\end{tabular}

Sources: developed by the authors.

The intergenerational comparison focused on fear perception from misusing personal, and payment data was conducted by statistical verifying by Pearson $\mathrm{X} 2$ test. The results revealed statistically significant differences between representatives of Generation Y. They, compared to Generation Z, are more afraid of misusing their personal and payment data when shopping in the e-commerce environment. Based on the results of statistical verification by Pearson $\mathrm{x} 2$ test, we can accept the $\mathrm{H} 0$ hypothesis and reject the alternative hypothesis on the significance level $p<0,01$ and the degrees of freedom 4 (Table 10).

Table 10. Statistical verification of the fourth hypothesis

\begin{tabular}{cccc}
\hline Pearson X2 test & $X^{2}$ & $p$ & df \\
\hline $\begin{array}{c}\text { Generation Y vs. } \\
\text { Generation Z }\end{array}$ & 16.74 & 0.002 & 4 \\
\hline
\end{tabular}

Sources: developed by the authors.

Table 11. Descriptive statistics and confidence intervals $(\mathrm{Cl})$ of the fourth hypothesis

\begin{tabular}{ccccccc}
\hline \multirow{2}{*}{ Options } & \multicolumn{3}{c}{ Generation $\mathbf{Y}$} & \multicolumn{3}{c}{ Generation Z } \\
\cline { 2 - 7 } & $\begin{array}{c}\text { Absolute } \\
\text { Frequency }\end{array}$ & $\begin{array}{c}\text { Relative } \\
\text { Frequency }\end{array}$ & $\begin{array}{c}95 \% \mathrm{Cl} \\
\text { (lower-upper) }\end{array}$ & $\begin{array}{c}\text { Absolute } \\
\text { Frequency }\end{array}$ & $\begin{array}{c}\text { Relative } \\
\text { Frequency }\end{array}$ & $\begin{array}{c}95 \% \mathrm{Cl} \\
\text { (lower-upper) }\end{array}$ \\
\hline Strongly disagree & 7 & 0.03 & $0.01-0.05$ & 11 & 0.025 & $0.01-0.04$ \\
Disagree & 89 & 0.315 & $0.26-0.37$ & 112 & 0.24 & $0.2-0.28$ \\
Neither agree nor & 71 & 0.255 & $0.2-0.31$ & 187 & 0.395 & $0.35-0.44$ \\
disagree & & & & & & \\
Agree & 99 & 0.355 & $0.3-0.41$ & 147 & 0.31 & $0.27-0.35$ \\
Strongly agree & 16 & 0.06 & $0.03-0.09$ & 19 & 0.04 & $0.02-0.06$ \\
\hline
\end{tabular}

Sources: developed by the authors.

The statistical verification of the last hypothesis was made by assuming the statistically significant difference in the preferred payment method between generation $Y$ and $Z$ representatives. In this case, the verification was conducted by Pearson $X^{2}$ test considered as the best-fitted test to reveal the differences between two observed samples. Based on the Pearson $X^{2}$ test results, the null hypothesis couldn't be accepted at the significance level $p<0,05$ and the degrees of freedom 3 (Table 12). The preferred payment 
R., Fedorko, V., Skerhakova, S., Markova, R., Bacik, L., Fejercak. Differences in the Perceived Financial Risk Factors between Digital Natives in the E-Commerce

methods of both examined generations while shopping online in e-commerce were online payment by credit/debit card and cash on delivery (COD).

Table 12. Statistical verification of the fifth hypothesis

\begin{tabular}{|c|c|c|c|c|c|c|}
\hline \multicolumn{2}{|c|}{ Pearson $\mathrm{X}^{2}$ test } & $x^{2}$ & \multicolumn{2}{|r|}{$p$} & \multicolumn{2}{|c|}{ df } \\
\hline \multicolumn{2}{|c|}{$\begin{array}{c}\text { Generation Y vs. } \\
\text { Generation Z }\end{array}$} & 0.93 & \multicolumn{2}{|c|}{0.818} & \multicolumn{2}{|c|}{3} \\
\hline \multicolumn{7}{|c|}{ Sources: developed by the authors. } \\
\hline \multicolumn{7}{|c|}{ Table 13. Descriptive statistics of the fifth hypothesis } \\
\hline \multirow[b]{2}{*}{ Options } & \multicolumn{3}{|c|}{ Generation Y } & \multicolumn{3}{|c|}{ Generation Z } \\
\hline & $\begin{array}{l}\text { Absolute } \\
\text { Frequency }\end{array}$ & $\begin{array}{c}\text { Relative } \\
\text { Frequency }\end{array}$ & $\begin{array}{c}95 \% \mathrm{Cl} \\
\text { (lower-upper) }\end{array}$ & $\begin{array}{l}\text { Absolute } \\
\text { Frequency }\end{array}$ & $\begin{array}{c}\text { Relative } \\
\text { Frequency }\end{array}$ & $\begin{array}{c}95 \% \mathrm{Cl} \\
\text { (lower-upper) }\end{array}$ \\
\hline $\begin{array}{l}\text { Cash of delivery } \\
\text { (COD) }\end{array}$ & 102 & 0.365 & $0.31-0.42$ & 183 & 0.385 & $0.34-0.43$ \\
\hline Internet banking & 48 & 0.175 & $0.13-0.22$ & 70 & 0.15 & $0.12-0.18$ \\
\hline Paypal & 21 & 0.08 & $0.05-0.11$ & 38 & 0.085 & $0.06-0.11$ \\
\hline $\begin{array}{l}\text { Online payment by } \\
\text { credit/debit card }\end{array}$ & 111 & 0.395 & $0.34-0.45$ & 185 & 0.39 & $0.35-0.43$ \\
\hline
\end{tabular}

Sources: developed by the authors.

Conclusion. This research focused on examining the differences in the perception of financial risk between the Digital Natives in the e-commerce environment revealed very significant findings in this problematics based on intergenerational differences. Table 14 observes the summary of the results of statistical verification of hypotheses.

Table 14. Summary of the results

\begin{tabular}{ccc}
\hline Hypothesis & Aspect & Result \\
\hline I. & The highest price that the respondents are willing to pay during one online & H0 accepted \\
purchase & The previous reputation of the e-shop & H0 rejected \\
II. & The level of willingness to provide personal and payment data & H0 accepted \\
III. & The level of perception of fear from misusing personal and payment data & H0 accepted \\
IV. & Preferred payment method & H0 rejected \\
V. &
\end{tabular}

Sources: developed by the authors.

Muhammad Shafeeque and Thomachan (2017) revealed that the risk perception of online shoppers is not significantly related to their income, sex, religion, and education. In turn, the results of statistical verification of formulated hypotheses concluded that the financial risk perception is significantly related to the age of the online shoppers regarding their generational membership. This conclusion is based on confirming statistically significant differences in this research. The first of them is observed in the amount of disposable budget for monthly purchases (excluding food expenditures) between female representatives of Generations $Y$ and $Z$, where the amount of disposable budget of the Generation $Y$ females was significantly higher than the amount of the Generation $Z$ females. Millennials mostly purchase online several times a month (44.7\%). Thus, it is obvious they have a higher disposable budget for purchases. Increasing the level of spending among online shoppers should be a key objective for online sellers (Swinyard and Smith, 2011). Also, the perspective view on the highest price, that the representatives of the Digital Natives are willing to pay in single online purchase, revealed that Generation $Z$ representatives are willing to spend a maximum of $50 €$. The height of this amount is probably influenced 
R., Fedorko, V., Skerhakova, S., Markova, R., Bacik, L., Fejercak. Differences in the Perceived Financial Risk Factors between Digital Natives in the E-Commerce

by the fact that most of Post-Millennials representatives do not have employment yet. They keep studying. Therefore, their disposable monthly budget is affected by the amount of «pocket money» from their parents or the number of hours spent working in their part-time jobs. The other barrier could be the less willing to provide their personal and payment data to the e-commerce subjects.

This research rests on intergenerational comparison revealed statistically significant differences between representatives of Generation Y, which, compared to Generation Z, are more afraid about misusing their personal and payment data while shopping online in the e-commerce environment. The Digital Natives spend more and more time on the Internet. This trend assures that any organization or the e-commerce subject which wants to gain a competitive privilege in the digital online environment should not forget about internet marketing. Horvath et al. (2014) confirmed the presence of the relationship between the trustworthiness of an e-business entity's website and its presentation on social media (e.g., Facebook and Instagram). The Digital Natives representatives most often use Facebook. Even though the Instagram social network is progressing globally in terms of its use by users, respondents use it less than the mentioned Facebook. The latest most commonly used social network for the Digital Natives is YouTube. All of the mentioned social networks provide with their innovative possibilities of promotion in Internet marketing the biggest opportunity for e-commerce subjects to react to the specific needs and desires of the Digital Natives on the way to build their trustworthiness and loyalty. That supports their positive attitudes to e-commerce subjects and online shopping. The last stated recommendation was considered as a practical marketing implication of this research.

Thee results confirmed that the previous reputation of the e-shop is considered as an important factor by the representatives of both examined generations which is compatible with the results of other researches focused on this problematics (Guo et al. 2012; Javadi et al. 2012; Stefko et al. 2013; a.0.). Sirkova (2015) stated that if the companies want to build and maintain their reputation, they should be obliged to implement ethical and moral principles in their business and financial activities. As the managerial implication of this examined factor, it is recommended that e-shops constantly keep their reputation in the online environment untouched and respond immediately to any negative reviews regarding customers' bad shopping experiences through their e-shop. Thus, ignoring this factor could significantly damage their reputation. However, there may be situations where all processes on the part of the e-shop are secured. Still, an error may occur due to the failure of the payment gateway or the bank, so it is necessary to identify where the error occurred if customers have a negative experience with the payment process. As the online payment intermediary is also part of the business and logistics cycle, its failure can affect consumers' perceptions of the whole e-shop and shopping through it. As part of building customer loyalty and attracting new ones, e-shops should respond to positive reviews, for example, by thanking them for their purchase or opinion. Paradoxically, representatives of Generation $Y$ stated that they are more willing to provide their personal and payment data to the e-commerce subjects than Generation Z. It means that the older generation is much more identified with the online digital world. This significant security risk aspect found out on intergenerational comparative analysis represents an advantage for online sellers in building loyal customers with a higher disposable budget for monthly online purchases and the higher amount willing to pay during a single online purchase. Besides, according to Prokopenko et al. (2016), increasing consumers' trust in e-commerce stimulates sales volume of the product of different categories through the Internet. These findings are compatible with the results of Javadi et al. (2012) on the analysis of financial risk factors affecting the online shopping behavior of consumers. Thus, the higher is the risk of losing money and the probability of disclosing credit card information, the lower positive attitude toward online shopping is. Online sellers could also encourage increasing the frequency of online payments and online shopping through a cashback system. A certain percentage of the total paid amount is returned to the customer's loyalty account.

Both generations agreed on the preferred payment method for online shopping, namely online card payment, and COD. The paradox of this perspective view on the financial and security risk is that the 
R., Fedorko, V., Skerhakova, S., Markova, R., Bacik, L., Fejercak. Differences in the Perceived Financial Risk Factors between Digital Natives in the E-Commerce

online payment by a credit/debit card is considered as the riskiest and trustworthy payment method in the online environment because of the necessity of providing personal and payment data to the e-commerce subjects. As a part of making online purchases, in this perspective view on the financial risk, it was observed that both representatives of examined generations prefer e-shops. They provide smooth, fast, and trouble-free payment methods. They refuse to perform lengthy processes, which wastes their time and requires more steps. A large selection of payment methods is important for them when choosing ecommerce subjects. They prefer online payment by credit/debit card and cash on delivery (COD). However, COD significantly slows down the cash flow of online sellers. Thus, it is recommended to reorient the outdated payment habits of the Digital Natives by supporting digital online payments, for example, in exchange for free special e-shop services to customers. According to Tej et al. (2015), in the current dynamically changing trading environment, all organizations need to generate new and innovative ideas, products, and solutions to the interest of their potential customers and keep their loyal customers. Another innovative managerial implication of this research recommendation is for e-commerce subjects (and Paypal itself). They need to raise awareness of the benefits of the Paypal payment method, increasing their cash flow in the future, reducing additional costs, and speeding up the entire purchasing process. According to Prokopenko et al. (2016), the website Aliexpress suggests quite a safe payment system. There is a special service Escrow, to which the money comes. But the seller receives it only after the buyer gets the parcel and confirms that he allows transit money.

This research offers a more comprehensive understanding of online consumer behavior and perceived financial and security risk factors related to shopping in the e-commerce environment of both generations (Millennials and Post-Millennials). The findings further confirm some previous research findings (Guo et al. 2012; Halaweh, 2018; Horvath et al., 2014; Javadi et al., 2012; McQuivey, 2000; Pencarelli et al., 2018; Prokopenko et al. 2016; Swinyard and Smith, 2011; Stefko et al., 2013; Teltzrow et al., 2007; Wright, 2016) and help to clarify and explain inconsistent conclusions from previous studies in the field of this problematics. This research has certain limitations, from whose the most significant one is that the questionnaire survey was conducted in a single geographical area (solely in the Slovak Republic). Crosscultural research could reveal more significant findings in this problematics. Thus, it can only be recommended to enlarge this research. Another limitation of this research was using the online questionnaire method in data collecting, according to which we couldn't secure the origin of the respondents only from the selected generations.

In future research, it is appropriate examining the existence or presence of a significant relationship between the willingness to provide personal and payment data and preferred payment method. Also, the existence of a relationship between this type of willingness and the highest price that the respondents are willing to pay during a single online purchase could reveal other interesting, important findings in the perception of the financial risk by the Digital Natives in e-commerce. The research on the level of trustworthiness of digital payment method Paypal by the Digital Natives could reveal the other possibilities for e-commerce subjects in reorientation and modernization of their payment habits.

Authors Contribution: conceptualization, R. F., V. S., S. M., R. B., and L'. F.; data curation, V. S. and R. F.; formal analysis, V. S.; funding acquisition, R. F. and R. B.; investigation, V. S.; methodology, V. S. and R. F.; project administration, R. F. and R. B.; resources, S. M. and L. F.; software, V. S.; supervision, R. F., V. S. and S.M.; validation, R. F. and R. B.; visualization, S. M. and L'. F.; writing - original draft, R. F. and V. S.; writing - review \& editing, S. M., R. B. and L'. F.

Funding: This research is one of the partial outputs under the scientific research grants VEGA $1 / 0694 / 20$ - «Relational marketing research - perception of e-commerce aspects and its impact on purchasing behaviour and consumer preferences» and VEGA 1/0609/19 - «Research on the development of electronic and mobile commerce in the aspect of the impact of modern technologies and mobile communication platforms on consumer behaviour and consumer preferences». 
R., Fedorko, V., Skerhakova, S., Markova, R., Bacik, L., Fejercak. Differences in the Perceived Financial Risk Factors between Digital Natives in the E-Commerce

\section{References}

Al Mazrouei, M., \& Krotov, V. (2016). Gender-related barriers to E-Commerce entrepreneurship: the case of the UAE. Polish Journal of Management Studies, 14(2), 7-17. [Google Scholar] [CrossRef]

Aldhmour, F., \& Sarayrah, I. (2016). An investigation of factors influencing consumers'intention to use online shopping: an empirical study in south of Jordan. Journal of Internet Banking and Commerce, 21(2), 1. [Google Scholar]

Barton, Ch., Kostow, L., \& Beauchamp, Ch. (2014). How Millennials Are Changingt heFace of Marketing Forever. Miguel Hernandez Communicaion Journal, 8, 347-368. Retrieved from [Link]

Bianchi, A. (2016). I Millennial Italiani in 5 punti, In: Casagrande Yamawaki, M., Sarfati, G. (2019). The Millennials Luxury Brand Engagement on Social Media: A Comparative Study of Brazilians and Italians. Revista Eletrônica de Negócios Internacionais, 14(1), 14-30. Retrieved from [Link]

Blaker, H. (2000). Confidence curves and improved exact confidence intervals for discrete distributions. Canadian Journal of Statistics, 28(4), 783-798. [Google Scholar] [CrossRef]

Bolton, R. N., Parasuraman, A., Hoefnagels, A., Migchels, N., Kabadayi, S., Gruber, T., ... \& Solnet, D. (2013). Understanding Generation $Y$ and their use of social media: a review and research agenda. Journal of Service Management, 24(3), 245-267. [Google Scholar] [CrossRef]

Chen, P. J., \& Choi, Y. (2008). Generational differences in work values: a study of hospitality management. International Journal of Contemporary Hospitality Management, 20(6), 595-615. [Google Scholar] [CrossRef]

Davidaviciene, V., Meidute-Kavaliauskiene,I., \& Paliulis, R. (2019). Research on the influence of social media on generation $Y$ consumer purchase decisions. Marketing and Management of Innovations, 4, 39-49. [Google Scholar] [CrossRef]

De Canio, F., Pellegrini, D., \& Aramendia-Muneta, M. E. (2016). The smartphoners: consumer segmentation by smartphone usage. The smartphoners: consumer segmentation by smartphone usage, 123-144. [Google Scholar]

Deloitte. (2019). The Deloitte Global Millennial Survey 2019. Retrieved from [Link]

Fietkiewicz, K. (2017). Jumping the digital divide: How do "silver surfers" and "digital immigrants" use social media?. Networking Knowledge: Journal of the MeCCSA Postgraduate Network, 10(1), 5-26. [Google Scholar] [CrossRef]

Gallo, P., Mihalcova, B., Vegsoova, O., Dzurov-Vargova, T., \& Busova, N. (2019). Innovative Trends in HumanResources Management: Evidence for the Health Care System. Marketing and Management of Innovations, 2, 11-20. [Google Scholar] [CrossRef]

Guo, X., Ling, K. C., \& Liu, M. (2012). Evaluating factors influencing consumer satisfaction towards online shopping in China. Asian Social Science, 8(13), 40. [Google Scholar]

Halaweh, M. (2018). Cash on delivery (COD) as an alternative payment method for e-commerce transactions: Analysis and implications. International Journal of Sociotechnology and Knowledge Development (IJSKD), 10(4), 1-12. [Google Scholar] [CrossRef]

Hanan, H., Wee, H., Aminudin, N., \& Hamid, Z. A. (2018). Effectiveness of social media campaigns in improving participation of younger generations in beach-cleaning programs. Advanced Science Letters, 24(12), 9266-9269. [Google Scholar] [CrossRef] $\underline{\text { Scholar] }}$

Hollander, M., Wolfe, D. A., \& Chicken, E. (2013). Nonparametric statistical methods (Vol. 751). John Wiley \& Sons. [Google

Horvath, J., Rigelský, M., Olearova, M. (2014). Analysing the Preferences in Customer Behaviour of a New Generation of Customers Through Smartphones in the Social Media Environment. Polish Journal of Management Studies, 18(2), 15-26 [Google Scholar]

Javadi, M. H. M., Dolatabadi, H. R., Nourbakhsh, M., Poursaeedi, A., \& Asadollahi, A. R. (2012). An analysis of factors affecting on online shopping behavior of consumers. International journal of marketing studies, 4(5), 81. [Google Scholar] [CrossRef]

Jurkiewicz, C. L. (2000). Generation X and the public employee. Public Personnel Management, 29(1), 55-74. Google Scholar[] CrossRef

Kleinman, P. (2012). Psych 101: Psychology Facts, Basics, Statistics, Tests, and More!. Simon and Schuster. [Google Scholar] Korzeniowska, A. (2015). Generation Y on the e-commerce market. Comparison between Polish and South Korean young consumers' behaviour. Journal of marketing and consumer behaviour in emerging markets, 2(2), 33-48. [Google Scholar]

Kowske, B. J., Rasch, R., \& Wiley, J. (2010). Millennials'(lack of) attitude problem: An empirical examination of generational effects on work attitudes. Journal of business and psychology, 25(2), 265-279. [Google Scholar] [CrossRef]

Kubilay, B., \& Bayrakdaroglu, A. (2016). An empirical research on investor biases in financial decision-making, financial risk tolerance and financial personality. International Journal of Financial Research, 7(2), 171-182. [Google Scholar] [CrossRef]

Lyulyov, O., Chygryn, O., \& Pimonenko, T. (2018). National brand as a marketing determinant of macroeconomic stability. Marketing and Management of Innovations, 3, 142-152. [Google Scholar] [CrossRef]

Magnani, G., Bertolotti, T., \& Zucchella, A. (2018). Cognitive aspects of car sharing in Millennials. Active sharers and reluctant users. Mercati e competitivit, 2018(1), 39-62. [Google Scholar] [CrossRef]

McQuivey, J. L., (2000). Why some young consumers don'tshop online. The Forrester Technographics Brief, June 2, 2000, Forrester Research, Inc. In: Swinyard, W. R., Smith, S. M. (2003). Why People (Don't) Shop Online: A Lifestyle Study of the Internet Consumer. Psychology and Marketing, 20(7):567 - 597. [CrossRef] 
Michalski, G., Brozyna, E. Soroczynski, J. (2015). Cash levels and its role in full operating cycle enterprises: 2005-2013 Czech, Slovak, Hungarian and Polish enterprises case. European Financial Systems 2015. Proceedings of the 12th International Scientific Conference, Brno: Masaryk University, p. 382-390. Retrieved from [Link]

Muhammad Shafeeque A.P., \& Thomachan K.T. (2017). Risk perception in e-commerce: a holistic review of emerging online shopping in India. International Journal of Research, 5(6), 231-239. [Google Scholar] [CrossRef]

Oczachowska, A. (2020). Purchase Behaviours of Generation Y. Annales Universitatis Mariae Curie-Skłodowska, Sectio H Oeconomia, 54(1), 67-75. [Google Scholar]

Paganini, A. (2019). Violenti o nolenti, la Gen Z e le insidie della rete. La cultura del progetto verso pratiche d'informazione alternative per i Centennials. [Google Scholar]

Park, J., \& Gursoy, D. (2012). Generation effects on work engagement among US hotel employees. international journal of Hospitality Management, 31(4), 1195-1202. [Google Scholar] [CrossRef]

Pencarelli, T., Skerhakova, V., Ali Taha, V., \& Valentiny, T. (2018). Factors determining Italian online shoppers' preference of cash on delivery: Empirical analysis. Polish Journal of Management Studies, 18. [Google Scholar] [CrossRef]

Prokopenko, O.V, Bozhkova, V. V., \& Romanyuk, Y. S., (2016). Modern internet platforms in the field of logistic service in the Republic of Poland and Ukraine. Marketing and Management of Innovations, 3, 54- 65. [Google Scholar]

Ryder, N. B. (1965). The Cohort as a Concept in the Study of Social Change. American Sociological Review, 843-861. [Google Scholar

Sirkova, M. (2015). Etika podnikania a firemna kultúra, PreSov: Bookman.

Stefko, R. (2013). Marketing naSej súcasnosti, PreSov: Bookman.

Swinyard, W. R., \& Smith, S. M. (2011). Activities, Interests, And Opinions Of Online Shoppers And Non-Shoppers. International Business \& EconomicsResearchJournal,3(4), 37-48. [CrossRef]

Tan, S. J. (1999). Strategies for reducing consumers' risk aversion in Internet shopping. Journal of Consumer Marketing, 16(2) 163-180. [Google Scholar] [CrossRef]

Tej, J., Taha, V. A., Bednarova, L., \& Sirkova, M. (2014, December). Management simulation exercises-Insight into their use in the educational process. In 2014 IEEE 12th IEEE International Conference on Emerging eLearning Technologies and Applications (ICETA) (pp. 29-34). IEEE. [Google Scholar] [CrossRef]

Teltzrow, M., Meyer, B., \& Lenz, H. J. (2007). Multi-channel consumer perceptions. Journal of Electronic Commerce Research, 8(1), 18-31. [Google Scholar] [CrossRef]

Thandava, M. K., \& Viju, S. (2017). A study on the financial risks and benefits of online shopping by the consumer. International Journal of Sales and Marketing Management, 6(4), 7-14.

Ungerman, O., Dedkova, J., \& Gurinova, K. (2018). The impact of marketing innovation on the competitiveness of enterprises in the context of industry 4.0. Journal of Competitiveness, 10(2), 132. [Google Scholar] [CrossRef]

Valaskova, K., Kliestik, T., Svabova, L., \& Adamko, P. (2018). Financial risk measurement and prediction modelling for sustainable development of business entities using regression analysis. Sustainability, 10(7), 2144. [Google Scholar] [CrossRef]

Wey Smola, K., \& Sutton, C. D. (2002). Generational differences: Revisiting generational work values for the new millennium. Journal of Organizational Behavior: The International Journal of Industrial, Occupational and Organizational Psychology and Behavior, 23(4), 363-382. [Google Scholar] [CrossRef]

Wright, A. I. (2016). Security Risk and Social Presence in E-commerce. Butler Journal of Undergraduate Research, 2(30), 197 230. Retrieved from [Link]

Річард Федорко, доцент, Пряшівський університет у Пряшеві, Словацька Республіка

Вероніка Скерхакова, Пряшівський університет у Пряшеві, Словацька Республіка

Стела Маркова, Пряшівський університет у Пряшеві, Словацька Республіка

Радован Бачик, доцент, Пряшівський університет у Пряшеві, Словацька Республіка

Любомир Феєрчак, Пряшівський університет у Пряшеві, Словацька Республіка

Цифрове суспільство та ринок е-соmerce: відмінності у сприйнятті фінансових ризиків

Фінансовим ризиком у сфері електронної комерції $є$ ймовірність неправомірного використання платіжних та персональних даних. При цьому на рівень фінансового ризик впливають такі фактори як: репутація інтернет-магазину, вибір способу оплати та вартість, яку споживач готовий заплатити за одну покупку. Результати систематизації наукових напрацювань засвідчили, що сприйняття фінансових ризиків має суттєве значення при формуванні довіри та лояльності суб'єктів електронної комерції. Це сприяє готовності споживачів витрачати більше коштів на онлайн-покупки. Головною метою статті є дослідження відмінностей у сприйнятті факторів фінансових ризиків в електронній комерції між інтернеткористувачами поколінь Z та Y. Підірунтям дослідження стали результати анкетування 758 інтернет-користувачів поколінь $\mathrm{Z}$ та Y. Практичну реалізацію всіх етапів дослідження здійснено з використанням непараметричних математико-статистичних кількісних методів (критерій узгодженості Пірсона, критерій непарних знакових рангів Уілкоксона). За результатами порівняльного аналізу встановлено, що представники покоління Y більш охоче надають свої персональні та платіжні дані. Таким чином, старше покоління значно більше ідентифікує себе із середовищем електронної комерції та її атрибутами. У ході дослідження підтверджено статистично значущі відмінності між поколіннями у побоюванні неправомірного використання персональних та платіжних даних. Представники покоління $Y \in$ більш занепокоєнні можливістю неправомірного 
R., Fedorko, V., Skerhakova, S., Markova, R., Bacik, L., Fejercak. Differences in the Perceived Financial Risk Factors between Digital Natives in the E-Commerce

використання їх персональних та платіжних даних під час здійснення покупок в онлайн середовищі. До того, представники покоління Y готові заплатити більшу суму за одну онлайн-покупку оскільки їх щомісячний бюджет на покупки є значно вищим (за винятком витрат на харчування). У дослідженні підтверджено відсутність відмінностей між поколіннями у сприйнятті репутації інтернет-магазину при прийнятті рішення про здійснення покупки та вибору способу оплати. Таким чином авторами емпірично доведено та теоретично обірунтовано суттєві відмінності у сприйнятті факторів фінансового ризику між інтернеткористувачами різних поколінь.

Ключові слова: фінансовий ризик, міжвіковй аналіз, міленіали, поведінка онлайн-споживачів, платіжне шахрайство, пост-міленіали. 